\title{
The Impact of Creative Construction Tasks on Visuospatial Information Processing and Problem Solving
}

\author{
Bernadett Babály ${ }^{1,2}$, Andrea Kárpáti ${ }^{3}$ \\ ${ }^{1}$ Szent István University, Ybl Miklós Faculty of Architecture and Civil \\ Engineering, Thököly út 74, H-1146 Budapest, Hungary \\ ${ }^{2}$ Eötvös Loránd University, Doctoral School of Education, \\ Kazinczy u. 23-27, H-1075 Budapest, Hungary \\ ${ }^{3}$ Eötvös Loránd University, Faculty of Science, \\ Pázmány Péter sétány 1/A, 7/7 25, H-1117 Budapest, Hungary \\ E-mail: babaly.bernadett@ybl.szie.hu; andrea.karpati@ttk.elte.hu
}

\begin{abstract}
This study explores the potential of using creative $3 D$ modeling for the development of spatial abilities. We investigate the efficiency of spatial training programs with a focus on differences in spatial information processing in real and virtual environments. Participants were architecture and civil engineering students in the first and second study year. The standardized Spatial Ability Test by Séra, Kárpáti and Gulyás (2002) was used for the assessment of relevant skill components: spatial perception, visualization and mental manipulation. In order to analyze visuospatial information processing and problem solving, we documented the phases of planning and modeling and revealed problems and motivating factors of the design process through student surveys. We discuss factors influencing the perception and interpretation of space and showed strategies of engineering students in solving spatial problems. The effectiveness of the program was unrelated to gender, specialization, secondary level studies and learning environments (real and virtual spaces). Post-test results of the experimental groups were significantly higher $(t[226]=-4.70, p<0.001)$ and the effect size of the developmental program was $d=1.07$. Research has proven that an appropriately constructed set of creative problem solving tasks in modeling and construction, results in significant development of spatial skills and are as effective as traditional drawing tasks. Creative modeling is an activity with high motivation value and can be utilized to develop spatial abilities that are basic for the professional development of engineers and architects.
\end{abstract}

Keywords: spatial abilities; creative problem solving; 3D modeling; project pedagogy; virtual learning environment 


\section{Introduction}

Creative problem solving is highly appreciated by educators, but rarely introduced in school curricula. In a teacher opinion survey by the European Commission on creativity, over $95 \%$ of respondents agreed that creativity is a fundamental competence that can be applied to every domain of knowledge and to every school subject, and therefore developed by every discipline at school [8]. The Partnership for $21^{\text {st }}$ Century Skills, an American organization of worldwide recognition that advocates the fusion of the three R's and four C's (critical thinking and problem solving, communication, collaboration and creativity and innovation), also emphasizes the importance of research-based examples to realize these objectives [36].

Visuospatial information processing is present in a wide range of everyday activities, from gardening or sewing to building self-representations on a social website. Construction challenges for knowledge building, develops problem solving skills and prepares for flexible retrieval and utilization of information in the world of work. Tens of thousands of people around the world organize peerlearning communities to acquire its technology and aesthetics as it is rarely taught in schools [12]. Image production (both in two- or three- dimensional formats) fosters the creation of accurate mental representations [27] [31]. Design and construction is associated with genetic forms of knowledge building: exploration, trial and play. The design process involves instinctive, spontaneous phases that may lead to inspiring detours and incongruences that result in the discovery of new solutions [1]. In the project reported here, we want to prove that open-ended, creative design and construction tasks may develop spatial skills with at least the same efficacy as traditional methods based on drill-like exercises in representational conventions. We also show that creative tasks inspire students at a university of technology, to produce high quality work that illustrates the development of their creativity, as well as, their spatial skills.

\section{The Role of Creative Construction Tasks in the Development and Assessment of Visuospatial Information Processing and Spatial Representation}

Visuospatial information processing and spatial representation (referred to as spatial skills in the subsequent part of this paper) are key areas of development in many educational disciplines. STEM (Science, Technology, Engineering and Mathematics) educators claim that spatial ability influences knowledge acquisition in their disciplines [7] [35] [45]. If one spatial skill component is developed, it may affect the level of others [39]. Different types of learning environments have special effects on the development of spatial skills [40] [42] [43]. 
Several research findings suggest that construction activities positively affect spatial skills as well as learning achievement in mathematics and science. Moreover, learning deficits may be revealed and individually treated in early childhood through construction game based tools [38]. In a project by Verdine, Golinkoff, Hirsh-Pasek, Newcombe, Filipowicz and Chang [47] studied the emergence of construction skills in relation to verbal literacy, numeracy, gender and social background. Both the development and the assessment were performed through building tasks with LEGO bricks: children had to build a construction out of 2-4 bricks according to a drawing. McKnight and Mulligan [29] saw the role of construction toys in activating intuitive, informal modes of knowledge acquisition and thus reveal the level of differentiated thinking. They used open-ended construction tasks for studying spatial problem solving skills. A similar research approach was employed by Ferrara, Hirsh-Pasek, Newcombe, Golinkoff and Lam [11] who developed spatial skills through three methods: (1) free play with building blocks; (2) guided play; (3) play with prefabricated constructions. No tasks were prescribed, but the researchers analyzed how children interacted with the educational environment through assembling and disassembling, constructing and reconstructing the blocks.

The major influential factor in the enhancement of spatial skills is teaching methodology. The developmental effects of construction, was first utilized systematically in education by Friedrich Froebel. Developed in the early 1800s for his Kindergarten, the Froebel Gifts appear deceptively simple but elicit a wide range of sophisticated operations described in detailed manuals. With a wide range of construction activities, he clearly aimed at the development of visuospatial information processing and through this, cognitive development: "From objects to pictures, from pictures to symbols, from symbols to ideas, leads the ladder of knowledge." (Froebel [13] quoted by Marenholtz-Buelow [30] p. 36). Most of the Froebel Gifts were monochrome: a clear indication of the emphasis on structural relationships among geometric elements, and not the imitation of real-life objects. Maria Montessori employed construction as a free experimentation method through which sensory organs may be developed. In the fifties, when the effects of construction on cognitive development became widely studied, her "Child Size Tools for Small Hands" series and her creative tasks based on experimentation inspired educational toys worldwide. The US Government encouraged the inclusion of building and construction in several curricular areas to promote learning in mathematics and science [16].

The meta-analysis by Nath and Szücs [34] of studies that indicate the effects of building and construction activities on performance in geometry and general spatial ability tests, claim that most studies lack data about background variables that might have influenced (and explained) results. In studies with sufficient background information, the effects of gender, social environment and verbal expression were revealed. Boys perform better in spatial tasks already at age 4, largely due to social conditioning by offering them building blocks and 
construction kits [25]. Richardson, Jones, Croker and Brown [38] are among the first to focus on educational implications and provide a system of tasks based on their difficulty and complexity. This model was used to construct a diagnostic test of cognitive development, based on LEGO toys. The test, validated for children aged 7-11 and adults, requires the building of a structure out of 4-11 LEGO bricks, based on isometric charts (similar to those used by IKEA for the assembly of furniture), within pre-set time limits.

There is no significant difference between the objectives and results of spatial development projects performed in real or virtual spaces. Both approaches are beneficial for skills enhancement and the reduction or even elimination of gender differences. Effect size is influenced by the frequency and quality of developmental programs. As the importance of digital technologies in education increases, the role of digital tools in the development of spatial skills is likely to increase as well. More authentic and research based educational methods will be employed to increase student motivation, provide individualized learning and also contribute to the development of $21^{\text {st }}$ Century skills [28].

Developmental programs, however, often neglect creative problem solving. In contemporary art education, examinations are required to include such tasks as they are necessary for reliable and authentic assessment of competences related to creation and perception of the arts. A modernized version of the portfolio of the $19^{\text {th }}$ Century art academies, the process folio that includes a logbook with documentation of research and variations on the theme leading to the final solution is a sensitive and flexible tool for the assessment of spatial intelligence [14]. Carefully chosen creative tasks have high intercultural validity as proven by the International Baccalaureate for the Arts [4]. A large scale Dutch-Hungarian study showed that project based portfolio assessment of creative work by trained jurors through detailed, illustrated evaluation criteria diminishing juror bias is a valid and reliable tool in education [18]. The reliability of assessment of visual skills may be increased through the introduction of creative design tasks and standardized competence tests at the same time [21].

Creative tasks as competence evaluation tools have a long tradition in higher education in the arts. Architectural or technical plans and artworks are used for final, summative assessment of professional skills at art and design academies and universities of technology as well. However, using open-ended, creative tasks for formative assessment regularly is far from being standard practice in engineering education as they are not considered objective measures of competence. In this paper, we show criteria for creative tasks to be used for the assessment of spatial creation and perception and prove that such tasks are not only motivating, but also valid measures of this basic for engineering work competence.

High student dropout numbers in technology education necessitated competence assessment of first and second year students at the Faculty of Architectural Studies at Szent István University, Budapest. The Mental Cutting Test was used to detect 
deficiencies in this area [5] [6] [22]. Similar studies preceded remedial skills development projects at other universities where deficient spatial skills resulted in learning problems [3] [33]. All three large-scale studies revealed difficulties in the development of spatial skills of 18-23-year-olds. University students could not completely overcome learning handicaps resulting from low levels of spatial perception and analysis. Many of them had to quit studies because of their inability to imagine or create three-dimensional objects represented in twodimensional plans and projections and vice versa. The results of several Hungarian studies correlate, with similar findings, showing the high impact of spatial skills deficiencies, in the failure in engineering studies [15] [24] [31] [42].

\section{Objectives and Methods of the Research Project}

We investigated factors influencing the development of spatial abilities with a focus on differences in spatial information processing in real and virtual spaces. In this paper we discuss the effects of methods based on the transfer effects of creative tasks in space on formal spatial representations.

Research questions:

Q1 Do creative problem solving tasks in modeling and construction result in significant development of spatial skills and are they as effective as traditional two-dimensional drawing tasks?

Q2 Is there significant difference in effect sizes between the two learning environments: modeling in real space and constructing models virtually?

Q3 Which factors influence the natural growth and educational enhancement of spatial abilities?

Q4 Which pedagogical methods and strategies are most suitable for the development of spatial abilities in the age range 18-22 years?

Related hypotheses:

H1 Gender influences spatial performance. Male students will score higher on the pre- and post-tests than female students.

H2 University level training type influences spatial performance. Civil engineering students would score higher on the pre- and post-tests than architects.

H3 Secondary school level training type influences spatial performance. Vocational secondary school graduates will outperform secondary grammar school graduates in the pre- and post-tests. 


\subsection{Sample}

The experiment was performed at the Faculty of Architectural Studies at Szent István University, Budapest, with students in the first and second study year. We targeted freshmen of architecture $(n=198)$ and civil engineering $(n=74)$ as both professions require, besides spatial perception (observation and interpretation of spatial relations, mental processing of visualizations, etc.) also creative skills (representation of shapes, spatial organization, modeling and construction based on an analysis of interrelationships of material, structure and form, etc.). The developmental program was introduced as an elective seminar. Students of the same study years who did not attend the spatial development program constituted the control groups. Pre-tests of spatial skills showed no significant difference between the experimental and control groups.

\subsection{Assessment Tools}

Spatial development experiments usually employ formal, standardized tests only for pre- and post- testing [46]. As our program focused on the effects of open, creative tasks, we also used process folios and a jurying method described in the papers surveyed in the introductory section for this paper. In order to document phases of visuospatial information processing, we documented phases of the creative process through films and photo sequences and on-site observation by external experts. A student questionnaire yielded information on skills and activities with potential influence on the development of spatial skills like engagement in visual arts, design or sports. Members of the experimental groups filled out satisfaction surveys as well. They evaluated the tutor's and their own performance and motivating factors as well as problems with working on an open ended art project (an unusual component in engineering studies).

The learning process was supported by an e-learning environment (Moodle) where study materials were shared and discussions about tasks documented. Problems with task solution were also managed through individual mentoring in private emails. The analysis of questionnaires, on-site observations and documentation provided by the virtual learning focused on a wide variety of aspects of the learning process: difficulties with understanding the tasks, quality of solution versions, correction and mentoring work and student motivation.

The formal assessment of development of spatial skills of 19-21 year old students was conducted by the Hungarian Spatial Ability Test by Séra, Kárpáti and Gulyás [41]. This test was successfully employed in large scale assessment projects both in secondary [19] and in higher education [10]. The two identical versions of the tool can be used for pre- and post-testing purposes (Version A, with 56 items and Version B with 47 items have a Cronbach's coefficient 0.81 and 0.93 , respectively). Besides task to be solved through selecting from alternative 
solutions through mental operations, the test also contains drawing tasks and can be used for the assessment of "thinking by drawing".

The test measures two large skills clusters, as described by Tóth (2014): A) Basic mental operations: mental analysis (observation of hidden spatial structures); mental synthesis (compositions); and B) Complex mental operations: mental rotation and transformation and construction of mental spatial images.

The test contains both object processing and spatial processing items components that have been identified by the Mental Imagery and HumanComputer Interaction Laboratory at Harvard University as representing the two dominant cerebral processing mechanisms of space [2] [23]. Those who use spatial processing, a dorsal visual pathway function, rely on spatial relations for orientation, while those who use object processing, a ventral visual pathway function, rely more on the characteristics of the objects in space (shape, color, texture and size). Tests including tasks for both orientation types are more reliable assessment instruments.

In this study, we describe the developmental program, show its effects on students of architecture and civil engineering and discuss interrelations among performance and background variables.

\subsection{The Experimental Program}

The experimental course was carried out during the Fall and Spring semesters of the academic year 2014/15. Students and tutors met thirteen times during a semester for 120-minute sessions. In the Fall semester, we formed three groups: a control group with students performing the usual spatial tasks of the course program only. (This program includes two-dimensional drawing tasks: perspective representation of arrangements of geometric shapes, furniture and interiors; reconstruction based on the Monge system; and structural drawing of objects.) (Figure 1)

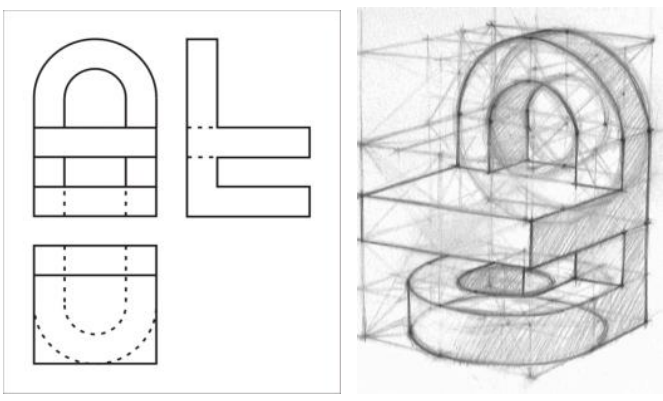

Figure 1

A two-dimensional reconstruction task for the control group studying in the traditional training program 
Our two experimental groups worked on similar three-dimensional modeling tasks but in different design environments: in real space, using different materials (cardboard, wood, textiles, glass) for building models and in virtual space, using computer-aided design - CAD - software for modeling. Constructing tasks range from simple to complex arrangements and focus on the relations of elements, the spatial structure and transformations like flexion, truncation, and proportion changes. The investigation of visual effects like plane and spatial form characters, rhythms, transparency, physical properties of materials, light and shadow effects are the most important components. The developmental program is intended to inspire analytic thinking and representation using spatial experiences and creative imagination that also reflects the designer's identity and personality. (Figs. 2, 3)
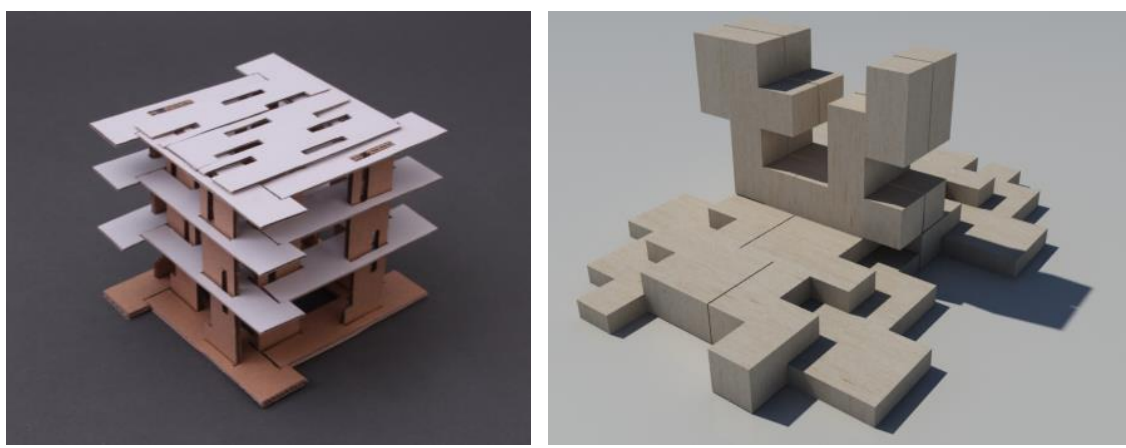

Figures 2 and 3

Spatial modeling developed according to tutor-defined criteria by Balázs Fehér, architect student, 2015 (in real space) and by Zsolt Vittay, architect student, 2015 (in virtual space)

Table 1

Representation methods, task types, experiment periods and sample sizes

\begin{tabular}{|c|c|c|c|c|c|}
\hline Groups & \multicolumn{2}{|c|}{$\begin{array}{l}\text { Two- or three- } \\
\text { dimensional type and } \\
\text { techniques of spatial } \\
\text { representation }\end{array}$} & $\begin{array}{c}\text { Tutor- } \\
\text { defined / } \\
\text { open task }\end{array}$ & $\begin{array}{l}\text { Semester in } \\
\text { the study year } \\
2014 / 2015\end{array}$ & $\begin{array}{l}\text { Sample } \\
\text { size }\end{array}$ \\
\hline Control group & $2 \mathrm{D}$ & $\begin{array}{l}\text { drawing } \\
\text { techniques }\end{array}$ & $\begin{array}{l}\text { tutor- } \\
\text { defined }\end{array}$ & Fall & 178 \\
\hline $\begin{array}{c}\text { 1. Experimental } \\
\text { group }\end{array}$ & $3 \mathrm{D}$ & $\begin{array}{c}\text { cardboard models } \\
\text { in real space }\end{array}$ & $\begin{array}{l}\text { tutor- } \\
\text { defined }\end{array}$ & $\begin{array}{l}\text { Fall and } \\
\text { Spring }\end{array}$ & 39 \\
\hline $\begin{array}{l}\text { 2. Experimental } \\
\text { group }\end{array}$ & $3 \mathrm{D}$ & $\begin{array}{c}\text { computer-assisted } \\
\text { design in virtual } \\
\text { space }\end{array}$ & $\begin{array}{l}\text { tutor- } \\
\text { defined }\end{array}$ & $\begin{array}{l}\text { Fall and } \\
\text { Spring }\end{array}$ & 35 \\
\hline $\begin{array}{l}\text { 3. Experimental } \\
\text { group }\end{array}$ & $3 \mathrm{D}$ & $\begin{array}{l}\text { models in real and } \\
\text { virtual space with } \\
\text { self-selected } \\
\text { materials and } \\
\text { techniques }\end{array}$ & open tasks & Spring & 20 \\
\hline
\end{tabular}


In the Spring semester, we repeated the course and also organized a third experimental group that worked on self-selected spatial problems through building three-dimensional models in real and virtual space. Members in this group, were also allowed to select materials and techniques for their models. (Figure 4)
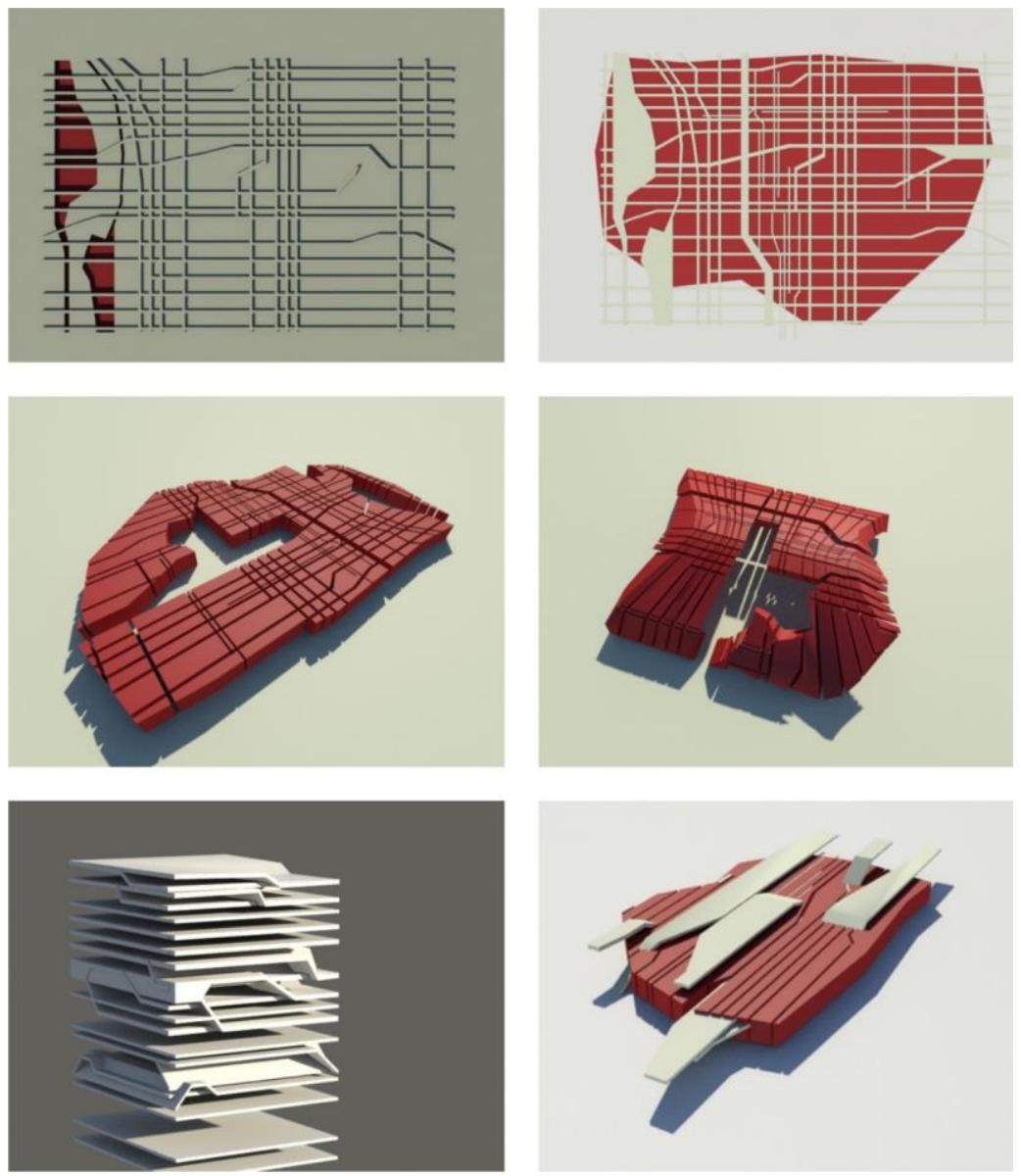

Figure 4

An open, creative task of spatial modeling by Balázs Veres, architect student, 2015

We used a process-oriented project method in all three experimental groups, organizing work around a design problem. This approach revealed problem solving strategies that usually remain hidden when task-oriented methods are used. In Groups 1 and 2, the tutor defined spatial problems to be solved through model building, and explained the phases of modeling and the technology to be used. Spatial problems for tasks were suggested by design tutors and represented real-life issues in architecture and civil engineering. Table 1 summarizes the educational methods and other data of the experimental and control groups. 


\section{Results}

Results of the pre- and post-tests show normal distribution, although some of the task groups of the Spatial Ability Test were easy for the architecture and Civil Engineering students. Pre-test average is $63.04 \%$ (skewness: -0.44, kurtosis: 0.12), post-test average is $72.01 \%$ (skewness: -0.99 , kurtosis: 1.17 ), cf. Figures 5 and 6.
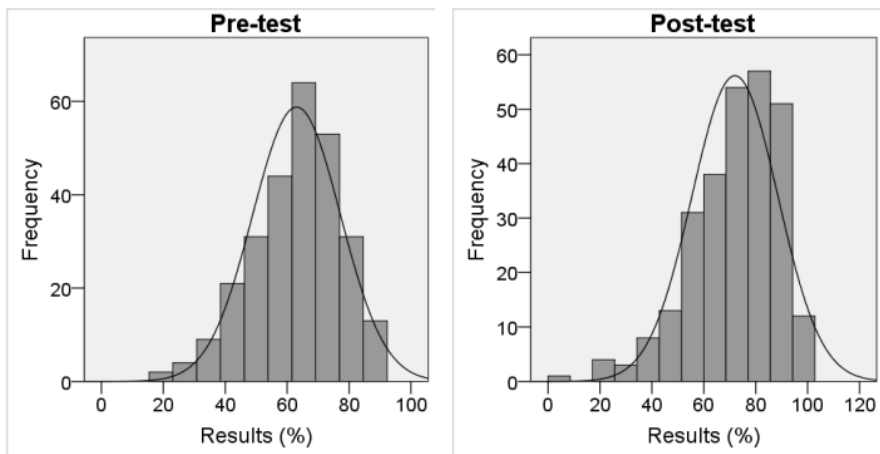

Figures 5 and 6

Distribution of results in the pre- and post-tests of the experimental and control groups $(\mathrm{N}=272)$

In the Fall semester, there were no significant differences between pre-test result of the students in the experimental and control groups. $\quad\left(\mathrm{M}_{\text {cont }}=62.16 \%\right.$, $\left.\mathrm{M}_{\text {exp }}=64.90 \% \mathrm{t}[226]=-1.28, \mathrm{p}<0.205\right)$. During the semester, the spatial skills of all groups developed significantly, $(\mathrm{t}[178]=-7.01, \mathrm{p}<0.001 ; \mathrm{t}[48]=-9.56, \mathrm{p}<0.001)$, but performance growth in the control group was only $6.48 \%$, while that of the experimental groups was $15.44 \%$. Post-test results of the experimental groups were significantly better $\left(\mathrm{M}_{\mathrm{cont}}=68.63 \%, \mathrm{M}_{\mathrm{exp}}=80.33 \%\right.$; $\left.\mathrm{t}[226]=-4.70, \mathrm{p}<0.001\right)$. Test results are summarized on Table 2 .

Table 2

Student performance on the Spatial Ability Test in the first experimental phase: a comparison of results of the experimental and control groups

\begin{tabular}{|c|c|c|c|c|c|}
\hline \multirow{2}{*}{ Groups } & \multicolumn{2}{|c|}{ Pre-test (\%) } & \multicolumn{2}{c|}{ Post-test $(\%)$} & $\begin{array}{c}\text { Pre- and post-test } \\
(\%)\end{array}$ \\
\cline { 2 - 6 } & Mean $\begin{array}{c}\text { Standard } \\
\text { deviation }\end{array}$ & Mean $\begin{array}{c}\text { Standard } \\
\text { deviation }\end{array}$ & $\begin{array}{c}\text { Paired-samples } \\
\mathrm{t} \text {-test }\end{array}$ \\
\hline Control (N=178) & 62.15 & 14.92 & 68.63 & 17.09 & $\mathrm{t}=-7.01, \mathrm{p}<0.001$ \\
\hline $\begin{array}{c}\text { Experimental } \\
(\mathrm{N}=48)\end{array}$ & 64.90 & 12.73 & 80.33 & 14.79 & $\mathrm{t}=-9.56, \mathrm{p}<0.001$ \\
\hline $\begin{array}{c}\text { Independent- } \\
\text { samples t-test }\end{array}$ & $\begin{array}{r}\mathrm{t}[226]=-1.28, \mathrm{p}<0.205 \\
\text { n.s. } *\end{array}$ & $\begin{array}{r}\mathrm{t}[226]=-4.70, \\
\mathrm{p}<0.001\end{array}$ & - \\
\hline
\end{tabular}

*not significant 
The effect size of the developmental program was $\mathrm{d}=1.07$, is more than 1 standard deviation. When we correct this value with the effect size of the development of the control group $(d=0.44)$, the resulting effect size is still $d=0.63$, a high value that shows the efficacy of the developmental programs based on creative threedimensional tasks.

On Figures 7 and 8, individual results of students are shown. Pre- and post-test scores are projected on top of each-other. Student whose performance was the same in both tests are shown on the diagonal. Above the diagonal, we can see students who performed better on the post test and under it, those who underperformed. On the left, results of members of the control group are almost evenly distributed above and below the diagonal. On the right, results of members of the experimental groups show two peculiar features. First, only those performed worse on the post-test, whose pre- and post-test results were very high. Second, there are many students with outstanding performance growth. Irrespective of higher or lower spatial skills levels at start, the experimental project resulted in substantial development.
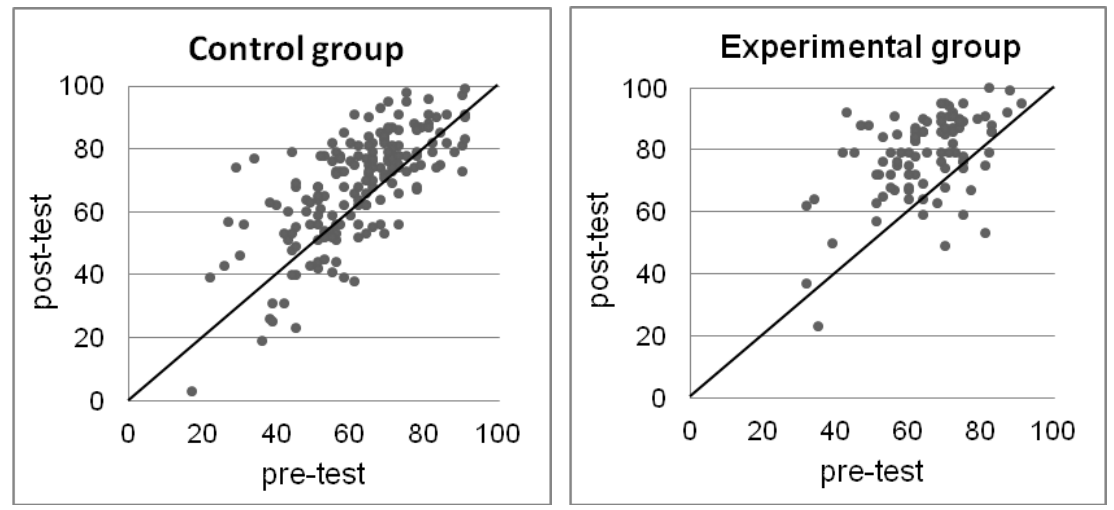

Figures 7 and 8

Results of the experimental and control groups in the pre- and post-tests ( $\mathrm{N}=272)$

The most important difference among the control and the experimental groups was the method of development through two- and three-dimensional tasks respectively. In the second phase of the experiment, we wanted to find out if it was the spatial representation modality (dimension) of the tasks or the spatial problems involved (the content of the developmental programs) that resulted in significant student development. Therefore, we organized an experimental group with a new type of training program, where students were allowed to select the spatial problems they wanted to solve and also the materials and threedimensional techniques employed. The performance of the two different types of experimental groups, are summarized on Table 3. 
Table 3

Results of the tutor-defined and the open task groups in the pre- and post-tests

\begin{tabular}{|c|c|c|c|c|c|}
\hline \multirow{2}{*}{$\begin{array}{c}\text { Type of } \\
\text { experimental } \\
\text { treatment }\end{array}$} & \multicolumn{2}{|c|}{ Pre-test $(\%)$} & \multicolumn{2}{c|}{ Post-test $(\%)$} & $\begin{array}{c}\text { Pre- and post-test } \\
(\%)\end{array}$ \\
\cline { 2 - 6 } & Mean & $\begin{array}{c}\text { Standard } \\
\text { deviation }\end{array}$ & Mean & $\begin{array}{c}\text { Standard } \\
\text { deviation }\end{array}$ & $\begin{array}{c}\text { Paired-samples } \\
\mathrm{t} \text {-test }\end{array}$ \\
\hline $\begin{array}{c}\text { Tutor-defined } \\
\text { modeling (N=74) }\end{array}$ & 64.30 & 12.66 & 80.01 & 13.00 & $\mathrm{t}=-11.60, \mathrm{p}<0.001$ \\
\hline $\begin{array}{c}\text { Open modeling } \\
(\mathrm{N}=20)\end{array}$ & 66.25 & 12.70 & 72.45 & 13.63 & $\begin{array}{c}\mathrm{t}=-1.82, \mathrm{p}<0.085 \\
\mathrm{n} . \mathrm{s} .{ }^{*}\end{array}$ \\
\hline $\begin{array}{c}\text { Independent- } \\
\text { samples t-test }\end{array}$ & \multicolumn{2}{|c|}{$\begin{array}{c}\mathrm{t}[94]=-0.61, \\
\mathrm{p}<0.542 \text { n.s. }\end{array}$} & $\mathrm{t}[94]=2.22, \mathrm{p}<0.034$ & - \\
\hline
\end{tabular}

*not significant

Results of the two experimental groups showed no significant difference in the pre-test $(\mathrm{t}[94]=-0.61, \mathrm{p}<0.542)$, and the distribution of results also had a similar pattern. (Levene-test $=0.17, \mathrm{p}=0.68$ ). The average performance growth of the open modeling task group was $6.20 \%$, but the development was not significant. The performance of the tutor-defined task group was significantly higher on the posttest, then on the pre-test $(\mathrm{M}=15.72 \% ; \mathrm{t}=-11.60, \mathrm{p}<0.001)$. The methodology of the developmental program (task types, structure of the teaching units etc.) contributed to student growth considerably $(\mathrm{t}[94]=2.22, \mathrm{p}<0.034)$. However, as the sample size for the open modeling group was relatively low $(n=20)$, we cannot decide if student development was the result of the methodology of the training program or just the better representational functions of the $3 \mathrm{D}$ environment. Further research is needed to establish the significance of the learning content and teaching methods in the development of spatial abilities through creative tasks.

In the Spring semester, we repeated the tutor-defined modeling program too. Results were similar to those in the Fall semester: experimental groups scored significantly higher than control groups, and the effect size of the tutor-defined modeling program was the same in both phases.

Table 4

Results of groups working in real and virtual space in the pre- and post-tests

\begin{tabular}{|c|c|c|c|c|c|}
\hline \multirow{2}{*}{$\begin{array}{c}\text { Type of modeling } \\
\text { environment }\end{array}$} & \multicolumn{2}{|c|}{ Pre-test $(\%)$} & \multicolumn{2}{c|}{ Post-test $(\%)$} & $\begin{array}{c}\text { Pre-and post-test } \\
(\%)\end{array}$ \\
\cline { 2 - 6 } & Mean $\begin{array}{c}\text { Standard } \\
\text { deviation }\end{array}$ & Mean & $\begin{array}{c}\text { Standard } \\
\text { deviation }\end{array}$ & $\begin{array}{c}\text { Paired-samples } \\
\mathrm{t} \text {-test }\end{array}$ \\
\hline $\begin{array}{c}\text { Material model (in } \\
\text { real space, N=39) }\end{array}$ & 65.18 & 12.81 & 78.62 & 15.21 & $\mathrm{t}=-7.14, \mathrm{p}<0.001$ \\
\hline $\begin{array}{c}\text { Digital model (in } \\
\text { virtual space, N=35) }\end{array}$ & 63.31 & 12.61 & 81.57 & 10.00 & $\mathrm{t}=-9.67, \mathrm{p}<0.001$ \\
\hline $\begin{array}{c}\text { Independent- } \\
\text { samples t-test }\end{array}$ & \multicolumn{2}{|c|}{$\begin{array}{c}\mathrm{t}[74]=-0.63, \\
\mathrm{p}<0.531 \text { n.s. } *\end{array}$} & \multicolumn{2}{|c|}{$\begin{array}{c}\mathrm{t}[74]=-1.00, \\
\mathrm{p}<0.322 \text { n.s. } *\end{array}$} & - \\
\hline
\end{tabular}

*not significant 
In both semesters, one of the experimental groups worked in virtual space, using CAD software. On Table 4 we compare the effects of spatial skills development in real versus in virtual space. There is no significant difference in effect sizes between the two learning environments: modeling in real space with tangible materials equally enhances spatial skills as constructing models virtually.

\section{Background Variables Affecting Student Results}

In this part of the paper, the effects of three background variables included in the student questionnaire will be discussed: gender, specialization (studies for an architecture or civil engineering degree), and secondary level education in a technical vocational school or secondary grammar school.

Table 5 shows test results by gender. Research on sex differences, in the level of spatial ability; almost always indicate the supremacy of boys and men [26]. We also hypothesized that both pre- and post-test results of male students would be higher. This assumption was justified in the present study as well. Another result, however, that indicates similar degree of development for men and women shows that spatial abilities of female engineering students with much lower pre-test scores than males may equally be enhanced through creative, three-dimensional tasks.

Table 5

Results of male and female students in the pre- and post-tests of the experimental and control groups

\begin{tabular}{|c|c|c|c|c|c|c|}
\hline \multirow{2}{*}{ Gender } & \multicolumn{2}{|c|}{ Pre-test $(\%)$} & \multicolumn{2}{|c|}{ Post-test (\%) } & \multicolumn{2}{|c|}{$\begin{array}{c}\text { Development } \\
\text { Pre-and post-test }(\%)\end{array}$} \\
\hline & Mean & $\begin{array}{l}\text { Standard } \\
\text { deviation }\end{array}$ & Mean & $\begin{array}{r}\text { Standard } \\
\text { deviation }\end{array}$ & Mean & $\begin{array}{l}\text { Standard } \\
\text { deviation }\end{array}$ \\
\hline Male $(\mathrm{N}=161)$ & 65.43 & 14.71 & 73.61 & 16.54 & 8.18 & 12.74 \\
\hline Female $(\mathrm{N}=111)$ & 59.57 & 12.71 & 69.69 & 16.34 & 10.13 & 13.39 \\
\hline $\begin{array}{c}\text { Independent } \\
\text { samples t-test }\end{array}$ & \multicolumn{2}{|c|}{$\begin{array}{c}\mathrm{t}[272]=3.50 \\
\mathrm{p}<0.001\end{array}$} & \multicolumn{2}{|c|}{$\begin{array}{l}\mathrm{t}[272]=1.93 \\
\mathrm{p}<0.055 \text { n.s. }\end{array}$} & \multicolumn{2}{|c|}{$\begin{array}{l}\mathrm{t}[272]=-1.21, \\
\mathrm{p}<0.226 \text { n.s. }\end{array}$} \\
\hline
\end{tabular}

*not significant

Male students scored significantly higher in the pre-test, $(\mathrm{t}[272]=3.50, \mathrm{p}<0.001)$, but in the post-test, their better performance is not so significant $(\mathrm{t}[272]=1.93$, $\mathrm{p}<0.055)$. In further studies, we will compare the level of development in relation to treatment types of the spatial skills development programs for female students to increase their performance in skill components that they seem to have a genetic or cultural handicap in. Female students showed lower performance in tasks that require mental manipulations like mental rotation and transformation. They achieved similar results in the recognition and interpretation of two- and threedimensional shapes. We could not detect gender-related differences in tasks that appear regularly in the university training programs (e.g. reconstruction). 
We also investigated the effects of specialization (studies for an architecture or civil engineering degree) on the results of spatial abilities development during the experimental courses. In the B.Sc. program for Civil Engineering, Mathematics and Technology is more pronounced than in the Bachelor in Architecture program. Therefore, we presumed that results of civil engineering students would be higher on both the pre- and post-tests. Contrary to our expectations, future architects performed significantly better than future civil engineers on both tests. (Cf. Table 6 for a comparison of results). There is no significant difference in their pace of spatial skills development either. The participants of our sample were all in their first or second year of study in a four-year degree course. It would be worthwhile to test the spatial skills of graduating students as well to verify this result and redesign courses if needed.

Table 6

Results of students of Architecture and Civil Engineering in the pre- and post-tests of the experimental and control groups

\begin{tabular}{|c|c|c|c|c|c|c|}
\hline \multirow{2}{*}{ Specialization } & \multicolumn{2}{|c|}{ Pre-test (\%) } & \multicolumn{2}{c|}{ Post-test (\%) } & \multicolumn{2}{c|}{$\begin{array}{c}\text { Development } \\
\text { Pre-and post-test (\%) }\end{array}$} \\
\cline { 2 - 7 } & Mean & $\begin{array}{c}\text { Standard } \\
\text { deviation }\end{array}$ & Mean & $\begin{array}{c}\text { Standard } \\
\text { deviation }\end{array}$ & Mean & $\begin{array}{c}\text { Standard } \\
\text { deviation }\end{array}$ \\
\hline Architect (N=198) & 66.34 & 12.76 & 76.06 & 13.03 & 9.72 & 12.46 \\
\hline $\begin{array}{c}\text { Civil engineer } \\
\text { (N=74) }\end{array}$ & 54.20 & 14.16 & 61.19 & 19.94 & 6.99 & 14.31 \\
\hline $\begin{array}{c}\text { Independent- } \\
\text { samples t-test }\end{array}$ & \multicolumn{2}{|c|}{$\begin{array}{c}\mathrm{t}[272]=6.46, \\
\mathrm{p}<0.001\end{array}$} & \multicolumn{2}{|c|}{$\begin{array}{c}\mathrm{t}[272]=5.96, \\
\mathrm{p}<0.001\end{array}$} & $\begin{array}{c}\mathrm{t}[272]=-1.45, \\
\mathrm{p}<0.150 \text { n.s.* }\end{array}$ \\
\hline
\end{tabular}

*not significant

University staff often report better performance of those students who are graduates of vocational secondary schools for whom it is easier to understand and solve tasks at the beginning of their training, than for students coming from secondary grammar schools. Based on this experience, we expected vocational secondary school graduates to outperform secondary grammar school graduates in the pre- and post-tests. Again, the hypothesis based on previous experiences turned out to be wrong: the type of secondary education had no effect on test results (cf. Table 7 for details). Tóth [44] compared the spatial ability of 14-18 year old students, of secondary grammar and vocational schools. Two important conclusions of the study: (1) some courses of the vocational training schools (like technical drawing) effectively develop spatial skills, (2) but the general cognitive abilities of secondary grammar school students are more advanced than those of vocational school students, and these positively affect their spatial performance. Consequently, spatial abilities of students from the two types of secondary education institutions are similar in the higher grades. It would be important to study the role of cognitive skills in future studies conducted with engineering students as well. 
Table 7

Results of graduates from vocational secondary schools and secondary grammar schools in the preand post-tests of the experimental and control groups

\begin{tabular}{|c|c|c|c|c|c|c|}
\hline \multirow{2}{*}{$\begin{array}{c}\text { Type of secondary } \\
\text { school }\end{array}$} & \multicolumn{2}{|c|}{ Pre-test (\%) } & \multicolumn{2}{c|}{ Post-test (\%) } & \multicolumn{2}{|c|}{$\begin{array}{c}\text { Development Pre- } \\
\text { and post-test (\%) }\end{array}$} \\
\cline { 2 - 7 } & Mean & $\begin{array}{c}\text { Standard } \\
\text { deviation }\end{array}$ & Mean & $\begin{array}{c}\text { Standard } \\
\text { deviation }\end{array}$ & Mean & $\begin{array}{c}\text { Standard } \\
\text { deviation }\end{array}$ \\
\hline $\begin{array}{c}\text { Secondary } \\
\text { grammar school }\end{array}$ & 63.04 & 14.35 & 71.38 & 16.06 & 8.34 & 12.50 \\
\hline $\begin{array}{c}\text { Vocational } \\
\text { secondary school }\end{array}$ & 63.03 & 14.03 & 73.02 & 17.37 & 9.99 & 13.80 \\
\hline $\begin{array}{c}\text { Independent- } \\
\text { samples t-test }\end{array}$ & \multicolumn{2}{|c|}{$\begin{array}{c}\mathrm{t}[272]=0.01, \\
\mathrm{p}<0.994 \text { n.s.* }\end{array}$} & \multicolumn{2}{|c|}{$\begin{array}{c}\mathrm{t}[272]=-0.78, \\
\mathrm{p}<0.436 \text { n.s. }\end{array}$} & \multicolumn{2}{|c|}{$\begin{array}{c}\mathrm{t}[272]=-1.00, \\
\mathrm{p}<0.319 \text { n.s. }\end{array}$} \\
\hline
\end{tabular}

*not significant

Creative and constructive task types have substantially developed the visual skill components studied. These tasks were especially useful for enhancing the ability to solve mental transformations and spatial operations requiring the integration of different viewpoints (construction of mental spatial images). They were also beneficial for the development of the other spatial skill components where this treatment also resulted in significant performance increase $(1 \mathrm{t}=-2,928, \mathrm{p}<0,005 ; 2$ $\mathrm{t}=-5,134, \mathrm{p}<0,001 ; 3 \mathrm{t}=-5,462, \mathrm{p}<0,001 ; 4 \mathrm{t}=-7,204, \mathrm{p}<0,001$ ). (Figure 9)

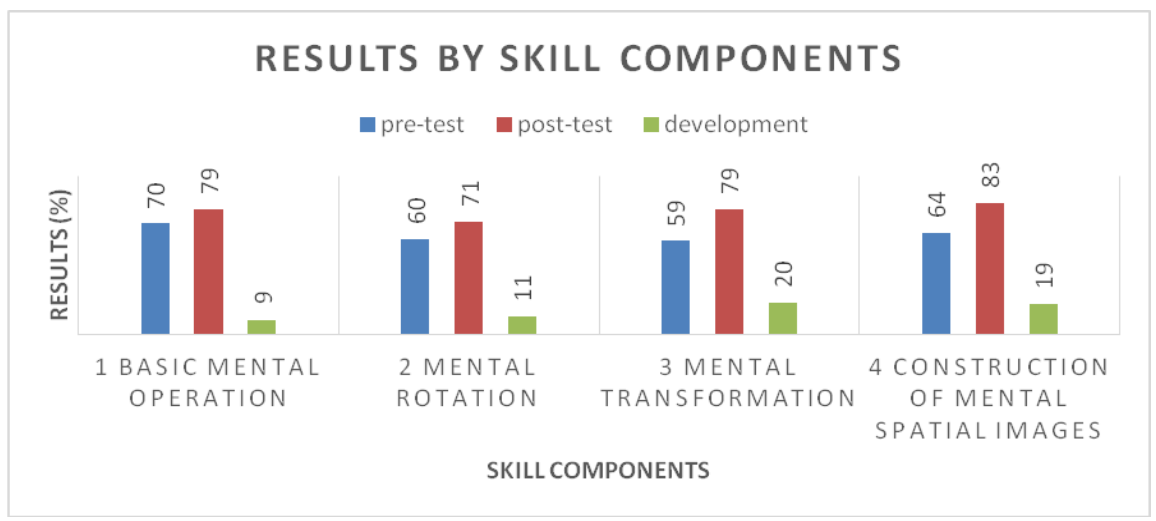

Figure 9

Results by spatial skill components in the pre- and post-tests ( $\mathrm{N}=74,1$ st and 2 nd experimental groups)

Female students performed lower in tasks requiring mental rotation and transformation, but in the integration of viewpoints and in the interpretation of shapes their performance was similar to those of male students. No gender-related differences were found in those tasks that are continuously present in the university training program (for example, reconstruction), - a result that indicates the possibility to reduce and eventually eliminate factors that result in weaker 
spatial performance of women. Results were not influenced by response type (choosing from alternatives or drawing the correct solution). Task difficulty was inherent in mental visualisation (creation of mental images). Tasks without response options represented as images resulted in more false answers.

Table 8 shows results for two issues raised in the survey: ranking problems encountered during the creative process and in the use of visual language by difficulty level. According to the process-oriented project method, tasks were organized in a logical sequence. This arrangement supported students in the identification of design problems and the elaboration of appropriate solutions. During the design experiment we could observe how students become more and more conscientious of spatial problems, how they learn to analyze them correctly and reflect with growing self-assurance on solutions of their own as well as those of peers.

\section{Table 8}

Frequency of responses on questions about the experimental program for the development of spatial skills (experimental groups)

\begin{tabular}{|c|c|c|}
\hline Question & Items ranked & $\begin{array}{l}\text { Frequency of } \\
\text { highest } \\
\text { ranking of } \\
\text { this item }(\%)\end{array}$ \\
\hline \multirow{5}{*}{$\begin{array}{l}\text { What was the most } \\
\text { difficult aspect of } \\
\text { solving the creative } \\
\text { task? } \\
\text { Rank the answer } \\
\text { choices in order of } \\
\text { preference, } 5 \text { being } \\
\text { the highest and } 1 \text { the } \\
\text { lowest! }\end{array}$} & U Understanding the task & 5 \\
\hline & Generating creative, original design ideas & 26 \\
\hline & $\begin{array}{l}\text { Finding the most appropriate technology (in a 3D } \\
\text { modeling task, selection of the most appropriate } \\
\text { material and tool, in computer aided design tasks, } \\
\text { the best software function, etc.) }\end{array}$ & 26 \\
\hline & $\begin{array}{l}\text { Preparation of the model (production of an } \\
\text { appropriate number of alternatives of good } \\
\text { quality) }\end{array}$ & 35 \\
\hline & $\begin{array}{l}\text { Corrections performed according to suggestions } \\
\text { by the tutor }\end{array}$ & 8 \\
\hline \multirow{6}{*}{$\begin{array}{l}\text { What were the major } \\
\text { problems in using } \\
\text { visual language? } \\
\text { Rank the answer } \\
\text { choices in order of } \\
\text { preference, } 6 \text { being } \\
\text { the highest and } 1 \text { the } \\
\text { lowest! }\end{array}$} & $\begin{array}{l}\text { Mental imaging and analysis of spatial } \\
\text { arrangements and their representation }\end{array}$ & 17 \\
\hline & Choice of color & 12 \\
\hline & $\begin{array}{l}\text { Design and interpretation of objects in space and } \\
\text { their connections }\end{array}$ & 10 \\
\hline & Texture design & 7 \\
\hline & Visual effects design & 17 \\
\hline & Composition & 37 \\
\hline
\end{tabular}

When ranking tasks by difficulty, students ranked the creation of model variations in adequate number and quality first or second. Tutors reported that students were often unable to plan the stages of task completion and considered their first design 
idea an accomplished task. They also found it difficult to come up with "creative and original" ideas. (In the second phase of the experiment, we divided the tasks in smaller subtasks and thus defined the process of activities in order to develop design skills more effectively).

First year students (freshmen) found the selection of appropriate techniques and processes for modeling difficult. In the use of visual language (e. g. creating different visual effects), students found tasks that required an exact interior image of the spatial situation to represent most difficult. Interpretation of spatial relations and design of visual effects were found difficult for the same reason: they both require mental modeling and complex mental manipulations (interpretation of spatial positions and directions, mental rotation and mirroring) before the completion of the task in real or virtual space. Even in the groups studied, first and second year students whose training focuses on the development high level spatial skills, it is difficult to harmonize different viewing angles. This deficit made students rank "composition" high on the list of difficult tasks.

The attitude survey of students participating in our experiment showed high level motivation for attendance in the creative modeling workshop. Students considered the enhancement of their general design competence, highly important for their future profession (and not the development of spatial skills) as their major benefit from the course. (Preference score given on a five-level Likert scale: 4,23).

\section{Conclusions}

Spatial ability is a basic set of skills for engineering students. It is traditionally developed through two-dimensional tasks in a geometric representational system, copying or drawing arrangements of geometric or organic objects. These activities are moderately motivating, even for art students. Therefore, our results for the successful enhancement of spatial skills, through creative modeling and construction tasks has a methodological significance. We have proven that an appropriately constructed set of tasks, supported by face-to-face and online mentoring, results in a significant developmental improvement.

Improved performance in spatial tests of the experimental groups was unrelated to gender, specialization and secondary level studies. Male, as well as, female students and future architects, as well as, engineers benefitted from the program, irrespective of being graduates of secondary vocational or grammar schools. The effect size of the development was close to the effect sizes reported in similar studies of near transfer between very similar contexts [9] [32] [37].

We found no difference between the test results of students working in real and virtual environments. Significant differences were only identified between those working with two-dimensional representations only (the control group) and the experimental groups working in real or virtual three-dimensional environments. Another influential factor was the developmental program: its quality impacted the level of the development of spatial ability. In a previous study, we tested five 
art education methodologies for students aged 10-14 [17]. Spatial ability was evaluated through standardized tests and revealed the primacy of the group that engaged in building and construction of objects in real space. Those groups, whose developmental program included only two-dimensional drawing tasks or perceptual tasks (analysis of geometric and artistic representations of space), developed slower. Similar findings were reported by János Katona [20] who found modeling tasks in a virtual, three-dimensional environment more effective for developing spatial skills. These findings and our research results reported here need further confirmation in different sociocultural and educational settings. It is probable that three-dimensional tasks like modeling and construction enhance the perception, processing and interpretation of spatial relations more effectively than traditional methods of two-dimensional representation.

Satisfaction surveys conducted after the two iterations of our experimental courses revealed a substantial "motivating effect" of the creative design and construction tasks. More frequent inclusion of such tasks in engineering programs is encouraged by the research. Free experimentation with design solutions and realization of plans in three-dimensional models are skills required of Architects and Civil Engineers.

Our future research will be focused on developmental differences of spatial ability of students of architecture and civil engineering that is present at the beginning of their training. Is it still there at the end of their training, and if so, what can we do to furnish future Civil Engineers with high level spatial skills? Another research problem is manifest in the lower developmental potential of freely selected modeling tasks. Work produced in this experimental group is of high quality, still this method does not seem to result in a similar level of skills enhancement as tutor-defined tasks. A more detailed analysis of test results (for example, the analysis of the strength of item to item correlations) may reveal which skill components are developed by the open, creative tasks develop, and which may be better enhanced through tutor-defined tasks with some creative options. We intend to introduce new testing measures that may assess a wider set of spatial skill components, to see which element of spatial ability the open, creative tasks develop that standardized spatial tests eventually neglect.

Apart from tests, we also evaluated the performance of students through portfolio assessment of their collections of design alternatives and finished products. Our future work will compare spatial ability development of students in the different experimental and control groups, based on a comparison of test results and portfolio assessment results. The current study has proven the effects of near transfer of a creative program. We intend to further improve this motivating and effective methodology and make it a research-grounded option for Universities of Technology. 


\section{References}

[1] Aden, M.: Risiken und Nebenwirkungen einer kompetenzorientierten Kunstpädagogik. Ein kritischer Forschungsbericht. Universität Bremen, Bremen. http://nbn-resolving.de/urn:nbn:de:gbv:46-00102369-13 Last accessed: 25 January 2016 (2011)

[2] Blazhenkova, O. and Kozhevnikov, M.: The New Object-Spatial-Verbal Cognitive Style Model: Theory and Measurement. Applied Cognitive Psychology, 23(5), pp. 638-663 (2009)

[3] Bárdné Feind, T.: Épitészhallgatók térszemléletének fejlödése és fejlesztése az Ábrázoló geometria tantárgy keretében. (Development and fostering of spatial abilities of students of architecture in a Descriptive Geometry seminar), Doctoral dissertation. Budapest University of Technology and Economics, Faculty of Architecture (2001)

[4] Boughton, D: Assessment of Performance in the Visual Arts: What, How, and Why. In: Karpati, A. and Gaul, E. (Eds.): From Child Art to Visual Culture of Youth - New Models and Tools for Assessment of Learning and Creation in Art Education. Intellect Press, Bristol (2013) pp. 119-142

[5] Bölcskei, A., Gál-Kállay, Sz., Kovács, A. Zs. and Sörös, Cs.: Development of Spatial Abilities of Architectural and Civil Engineering Students in the Light of the Mental Cutting Test. Journal for Geometry and Graphics, 16(1) pp. 103-115 (2012)

[6] Bölcskei, A., Kovács, A. Zs. and Kusar, D.: New Ideas in Scoring the Mental Rotation Test. Ybl Journal of Built Environment, 1(1) pp. 59-69 (2013)

[7] Cheng, Y. L. and Mix, K. S.: Spatial Training Improves Children's Mathematics Ability. Journal of Cognition and Development, 15(1) pp. 2$11(2014)$

[8] Creativity of Schools in Europe - a Survey of Teachers. European Commission, Paris (2009)

[9] Csíkos, Cs., Szitányi, J. and Kelemen, R.: The Effects of Using Drawings in Developing Young Children's Mathematical Word Problem Solving: A Design Experiment with Third-Grade Hungarian Students. Educational Studies in Mathematics, 81(1) pp. 47-65 (2012)

[10] Csíkos, Cs. and Kárpáti, A.: Connections between Spatial Ability and Visual Imagery Preferences. Journal of Engineering (Submitted)

[11] Ferrara, K., Hirsh-Pasek, K., Newcombe, N. S., Golinkoff, R. M. and Lam, W. S.: Block Talk: Spatial Language during Block Play. Mind, Brain, and Education, 5(3) pp. 143-151 (2011)

[12] Freedman, K., Hejnen, E., Kallio-Tavin, M., Kárpáti, A. and Papp, L.: Visual Culture Networks for Learning: What and How Students Learn in 
Informal Visual Culture Groups. Studies in Art Education, 54(2) pp. 103115 (2013)

[13] Froebel, F.: Die Grundsätze, der Zweck und das innere Leben der allgemeinen deutschen Erziehungsanstalt in Keilhau bei Rudolstadt. Müller Verlag, Erfurt. (1821)

[14] Gardner, H.: Art Education and Human Development. The Getty Center for Education in the Arts, Los Angeles (1990)

[15] Güven, B. and Kosa, T.: The Effect of Dynamic Geometry Software on Student Mathematics Teachers' Spatial Visualization Skills. Development, 2 (3D) (2008)

[16] Hewitt, K.: Blocks as a Tool for Learning: A Historical and Contemporary Perspective. Young Children, 56(1) pp. 6-14 (2001)

[17] Kárpáti, A.: The Leonardo Program. In: Kauppinen, H. and Dicket, M. (Eds.): International Trends in Art Education. NAEA, Washington. pp. 82$96(1995)$

[18] Kárpáti, A., Zempléni, A., Verhelst, N. V., Velduijzen, N. H. and Schönau, D. W.: Expert Agreement in Judging Art Projects - a Myth or Reality? Studies in Educational Evaluation, 24(4) pp. 385-404 (1998)

[19] Kárpáti, A. and Gaul, E.: From Child Art to Visual Language of Youth: The Hungarian Visual Skills Assessment Study. International Journal of Art Education, 9(2) pp. 108-132 (2011)

[20] Katona, J.: A geometriai térszemlélet számítógéppel támogatott fejlesztése a müszaki felsőoktatásban (Computer-supported Development of Geometric Perception of Space), Doctoral dissertation. Debrecen University (2012)

[21] Koch, D. S.: The Effects of Solid Modeling and Visualization on Technical Problem Solving. Doctoral dissertation, Virginia Polytechnic Institute and State University (2006)

[22] Kovács, A. Zs. and Németh, L.: Development of Spatial Ability according to Mental Rotation Test at SKF and YBL. Ybl journal of built environment, 2(1), pp. 18-29 (2014)

[23] Kozhevnikov, M. and Garcia, A.: Visual-Spatial Learning and Training in Collaborative Design in Virtual Environments. In Wang, X. and Jen-Hung J. (Eds.): Collaborative design in virtual environments - Intelligent Systems, Control and Automation: Science and Engineering, Springer Netherlands, 48, pp. 16-27 (2011)

[24] Leopold, C.: Geometry Education for Developing Spatial Visualisation Abilities of Engineering Students. Journal of Polish Society for Geometry and Engineering Graphics, 15, pp. 39-45 (2005) 
[25] Levine, S. C., Ratliff, K. R., Huttenlocher, J. and Cannon, J.: Early Puzzle Play: a Predictor of Pre-Schoolers' Spatial Transformation Skill. Developmental psychology, 48(2) pp. 530-542 (2012)

[26] Linn, M. C., and Petersen, A. C.: Emergence and Characterization of Sex Differences in Spatial Ability: A Meta-Analysis. Child development, 56(6) pp. 1479-1498 (1985)

[27] Mc Kim, R. H.: Experiences in Visual Thinking. MA: PWS Publishers, Boston (1980)

[28] McClarty, K. L., Orr, A., Frey, P. M., Dolan, R. P., Vassileva, V. and McVay, A.: A Literature Review of Gaming in Education. Gaming in Education. http://www.pearsonassessments.com/research. Last accessed: 25 January 2016 (2012)

[29] McKnight, A. and Mulligan, J.: Teaching Early Mathematics "Smarter not Harder": Using open-ended tasks to build models and construct patterns. Australian primary Mathematics Classroom, 15(3), pp. 4-9 (2012)

[30] Marenholtz-Buelow, B. Von: The Child and Child Nature. Forgotten Books, London (2013)

[31] Mohler, J. L., and Miller, C. L.: Improving Spatial Ability with Mentored Sketching. Engineering Design Graphics Journal, 72(1), pp. 19-27 (2009)

[32] Molnár, Gy.: Playful Fostering of 6- to 8-year-old Students' Inductive Reasoning. Thinking Skills and Creativity, 6(2), pp. 91-99 (2011)

[33] Nagyné Kondor, R.: Dinamikus geometriai rendszer bevezetése a gépészmérnök hallgatók müszaki ábrázolás oktatásába (Introduction of dynamic geometric systems in technological drawing studies of mechanical engineering students), Doctoral dissertation. Debrecen University (2007)

[34] Nath, S. and Szücs, D.: Construction Play and Cognitive Skills Associated with the Development of Mathematical Abilities in 7-year-old Children. Learning and Instruction, 32, pp. 73-80 (2014)

[35] Newcombe, N. S.: Seeing relationships: Using Spatial Thinking to Teach Science, Mathematics, and Social Studies. American Educator, 37(1), pp. 26-31 (2013)

[36] Partnership for 21. Century Learning: What We Know About CREATIVITY. Part of the 4Cs Research Series. http://www.p21.org/storage/documents/docs/Research/P21_4Cs_Research_ Brief_Series_-_Creativity.pdf Last accessed: 25 January 2016 (2015)

[37] Pásztor, A.: Lehetőségek és kihívások a digitális játék alapú tanulásban: egy induktív gondolkodást fejlesztő program hatásvizsgálata (Potentials and challenges of digital game based learning: usability study of a software for the development of inductive thinking) Magyar Pedagógia, 114(4), pp. 281-302 (2014) 
[38] Richardson, M., Jones, G., Croker, S. and Brown, S. L.: Identifying the Task Characteristics that Predict Children's Construction Task Performance. Applied Cognitive Psychology, 25(3), pp. 377-385 (2011)

[39] Salat, A. E. and Séra, L: A téri vizualizáció fejlesztése transzformációs geometriai feladatokkal (The development of spatial visualisation skills through transformative geometry tasks). Magyar Pedagógia, 102(4), pp. 459-473 (2002)

[40] Sandstrom, N. J., Kaufman, J. and Huettel, S. A.: Males and Females use Different Distal Cues in a Virtual Environment Navigation Task. Cognitive Brain Research, 6(4), pp. 351-360 (1998)

[41] Séra, L., Kárpáti, A. and Gulyás, J.: A térszemlélet. A vizuális-téri képességek pszichológiája, fejlesztése és mérése (Spatial ability. Psychology, development and assessment of visuospatial skills) Comenius Kiadó, Pécs (2002)

[42] Sorby, S. A.: Developing 3-D Spatial Visualization Skills. Engineering Design Graphics Journal, 63(2) pp. 21-32 (2009)

[43] Sutton, K., Heathcote, A. and Bore, M.: Measuring 3-D Understanding on the Web and in the Laboratory. Behavior Research Methods, 39(4) pp. 926939 (2007)

[44] Tóth, P.: Téri képességek, mentális müveletek (Spatial Abilities, Mental Operations) In: Buda, A. and Kiss, E. (Eds.): Interdiszciplináris pedagógia és a fenntartható fejlődés: A VIII. Kiss Árpád Emlékkonferencia előadásainak szerkesztett változata (Interdisciplinary pedagogy and sustainable development) Kiss Árpád Archívum Könyvtára - DE Neveléstudományok Intézete, Debrecen (Library of the Árpád Kiss Archive - Debrecen University, Institute of Educational Research) (2014) pp. 76-91

[45] Uttal, D. H. and Cohen, C. A.: Spatial Thinking and STEM Education: When, why and how. Psychology of learning and motivation, 57, pp. 147181 (2012)

[46] Uttal, D. H., Meadow, N. G., Tipton, E., Hand, L. L., Alden, A. R., Warren, C. and Newcombe, N. S.: The Malleability of Spatial Skills: a MetaAnalysis of Training Studies. Psychological bulletin, 139(2) pp. 352-402 (2013)

[47] Verdine, B. N., Golinkoff, R. M., Hirsh-Pasek, K., Newcombe, N. S., Filipowicz, A. T. and Chang, A.: Deconstructing Building Blocks: PreSchoolers' Spatial Assembly Performance Relates to Early Mathematical Skills. Child development, 85(3) pp. 1062-1076 (2013) 